\title{
Design proposal for a progressive die
}

\section{Propuesta de diseño de un troquel progresivo}

TUDÓN-MARTÍNEZ, Alberto†*, ZÚÑIGA-MARTÍNEZ, Marco Antonio, GARCÍA-CASTILLO, Ilse Nallely and ROSALES-GALLEGOS, Israel Atzin

Universidad Tecnológica de San Luis Potosí, Prol. Av. Dr. Arturo Nava Jaimes, Rancho Nuevo, Soledad de Graciano Sánchez, S. L. P.

ID $1^{\text {st }}$ Author: Alberto, Tudón-Martínez / ORC ID: 0000-0003-1689-1250, CVU CONACYT ID: 411753

ID $1^{\text {st }}$ Co-author: Marco Antonio, Zúñiga- Martínez / ORC ID: 0000-0003-2736-9177, CVU CONACYT ID: 94933

ID $2^{\text {nd }}$ Co-author: Ilse Nallely García-Castillo / ORC ID: 0000-0001-9602-2869, arXiv Author ID: IlseGarcia, CVU CONACYT ID: 668657

ID $3^{\text {rd }}$ Co-author: Israel Atzin, Rosales-Gallegos / ORC ID: 0000-0003-1485-9601, Researcher ID Thomson: AAR-78092021, CVU CONACYT ID: 372002

DOI: $10.35429 /$ JID.2021.13.5.10.15

Received July 23, 2021; Accepted October 30, 2021

\begin{abstract}
The objective of this project is to elaborate a design proposal for a progressive die to help reduce the manufacturing cycle time of a metal part in a diecutting machine and contribute to increasing the number of parts produced. The methodology used to prepare the progressive die design proposal is concurrent engineering, also known as simultaneous engineering or total engineering; it consists of a methodology where the design of the product is integrated into all the necessary processes to manufacture it. (F, 2003); It is the guide of each one of the phases that have been set in the design, such as conceptual and functional design and retail design; all this in order to take into account the requirements, parts, functions, manufacturing and construction to materialize the ideas that are proposed in this.
\end{abstract}

Proposal, Design, Machine

\section{Resumen}

El objetivo del presente proyecto es la elaboración de una propuesta de diseño de un troquel progresivo para contribuir a reducir el tiempo de ciclo de fabricación de una pieza metálica en una máquina de troquelado y contribuir al incremento del número de piezas producidas La metodología que se utiliza para la elaboración de la propuesta de diseño del troquel progresivo es la ingeniería concurrente, también conocida como ingeniería simultánea o ingeniería total; consiste en una metodología dónde el diseño del producto está integrado en todos los procesos necesarios para fabricarlo. ( $F, 2003$ ); es la guía en cada una de las fases que se han fijado en el diseño, como lo son el diseño conceptual y funcional y diseño de detalle; todo esto con el fin de que se tengan en cuenta los requerimientos, piezas, funciones, fabricación y la construcción para materializar las ideas que en este se proponen.

\section{Propuesta, Diseño, Máquina}

Citation: TUDÓN-MARTÍNEZ, Alberto, ZÚÑIGA-MARTÍNEZ, Marco Antonio, GARCÍA-CASTILLO, Ilse Nallely and ROSALES-GALLEGOS, Israel Atzin. Design proposal for a progressive die. Journal Innovative Design. 2021, 5-13: 10-15

\footnotetext{
*Correspondence to the Author (e-mail: atudon@utslp.edu.mx)

$\dagger$ Researcher contributing as first author.
} 


\section{Introduction}

There is a constant need for companies to continuously improve production processes and develop products that meet customer needs in terms of service, cost and delivery.

A company dedicated to the manufacturing sector has the need to make improvements in the production process, because in recent years the demand for its products by its customers has increased. The manufacturing process that it uses consists of several operations that are carried out independently in several die-cutting machines to bend and cut, consuming long times in the elaboration of metal parts, for this reason it is considered necessary to make improvements in the production process.

The hypothesis of the project is that by carrying out the necessary operations for the elaboration of the metal part with a single die, the cycle time will be reduced, since it will not be necessary to carry out die changes to carry out each operation that is required in the process of manufacture of the piece, in this way it will contribute to time reduction for elaboration of the piece and contribute to the increasement of production keeping the company in a competitive market.

\section{Development of Sections and Sections of the Article with subsequent numbering.}

In the die design methodology, the reference of the engineering design process is considered (Victorino, 2003), which contemplates the stages shown in Figure 1.

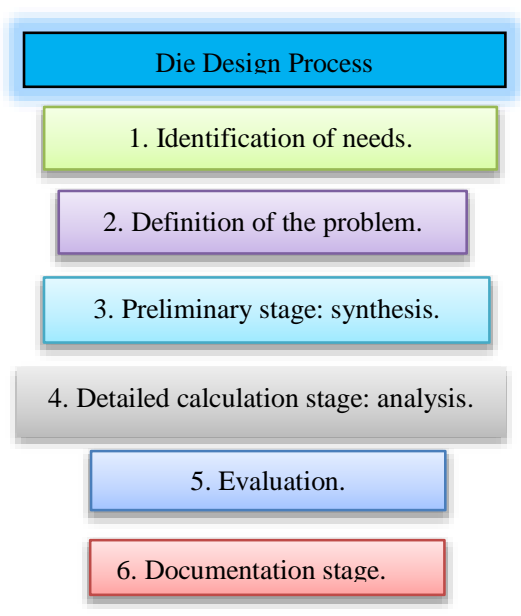

Figure 1 Design methodology

Source (project contribution, unpublished)

\section{Identification of needs}

A list of specifications is drawn up in a concise and not so extensive way, which is presented in table 1, where a sketch of only two of the machine concepts is shown in one format (Riba, 2006)], in where the specifications are: for design C: Customer; I: Engineer; A: Required; D: Desired

\begin{tabular}{|c|c|c|c|}
\hline $\begin{array}{c}\text { Universidad } \\
\text { Tecnológica de San } \\
\text { Luis Potosí } \\
\end{array}$ & \multicolumn{2}{|c|}{ Date: } & $\begin{array}{l}\text { Product: } \\
\text { Design of a die for the } \\
\text { manufacture of part }\end{array}$ \\
\hline Business: & \multicolumn{2}{|c|}{ Revision: } & 317B8422P002 \\
\hline \multicolumn{4}{|c|}{ Initial specifications } \\
\hline Concept & $\mathrm{C} / \mathrm{I}$ & $\mathrm{R} / \mathrm{D}$ & Description \\
\hline \multirow{3}{*}{ Function } & I & $\mathrm{R}$ & $\begin{array}{l}\text { Reliable for implementation } \\
\text { and reduction of production } \\
\text { times. }\end{array}$ \\
\hline & I & $\mathrm{R}$ & Consume fewer resources \\
\hline & I & D & $\begin{array}{l}\text { Produce the part in a shorter } \\
\text { time than the current process. }\end{array}$ \\
\hline \multirow{4}{*}{ Necessary operations } & I & $\mathrm{R}$ & $\begin{array}{l}\text { Carry out the cut of the piece } \\
\text { with the same die. }\end{array}$ \\
\hline & $\mathrm{I}$ & $\mathrm{D}$ & Reduce cycle time by $50 \%$ \\
\hline & $\mathrm{I}$ & $\mathrm{R}$ & Use only one press \\
\hline & I & $\mathrm{R}$ & $\begin{array}{l}\text { Produce one part for each die } \\
\text { stroke }\end{array}$ \\
\hline Precision & I & $\mathrm{R}$ & $\begin{array}{l}\text { The first precision inspection } \\
\text { is done with materials, } \\
\text { dimensions and cycle times. }\end{array}$ \\
\hline
\end{tabular}

Table 1 Machine concepts

Source (project contribution, unpublished)

\section{Definition of the problem}

It is important to consider the main characteristics of the part to be manufactured, which are determined at this stage, such as material, tolerances, in addition to the required production.

1. Material: galvanized steel B8A26G5 $0.060 "+/-0.002 "$ [1.524 +/- 0.051].

2. All holes in the part should have a tolerance of $+0.001 "-0.003$ " [+0.025 $0.076]$

3. Annual production 90,000 pieces.

\section{Preliminary stage: synthesis}

The part to be manufactured is analyzed to determine the necessary operations for the manufacture of the part, which are considered to define the types of elements that the progressive die must contain and be able to satisfy the client's needs. 
In this analysis, three types of operations will be determined, which are: Planes (P), Punching (PZ) and bends (D), which are shown in Figure 2.

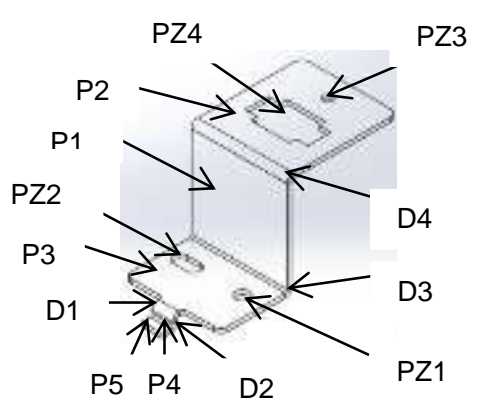

Figure 2 Necessary operations.

Source (project contribution, unpublished)

Table 2 shows the components nomenclature of the part, which are defined according to each element of the part.

\begin{tabular}{|c|c|l|}
\hline Elements & \multicolumn{2}{c|}{ Nomenclature } \\
\hline \multirow{4}{*}{ Planes } & P1 & Intermediate plane \\
\cline { 2 - 3 } & P2 & Upper horizontal plane \\
\cline { 2 - 3 } & P3 & Lower horizontal plane \\
\cline { 2 - 3 } & P4 & Lower vertical plane located at P3 \\
\cline { 2 - 3 } & P5 & Lower horizontal plane located at P3 \\
\hline \multirow{5}{*}{ Punching } & PZ1 & Punching located at P3 \\
\cline { 2 - 3 } & PZ2 & Punching located at P3 \\
\cline { 2 - 3 } & PZ3 & Punching located in the P2 \\
\cline { 2 - 3 } & PZ4 & Punching located in the P2 \\
\hline \multirow{5}{*}{ Folds } & D1 & Fold linking P4 and P5 \\
\cline { 2 - 3 } & D2 & Fold linking P4 and P3 \\
\cline { 2 - 3 } & D3 & Fold linking P1 and P3 \\
\cline { 2 - 3 } & D4 & Fold linking P1 and P4 \\
\hline
\end{tabular}

Table 2 Nomenclature of the components of the part Source (project contribution, unpublished)

Elaboration of a relational diagram of the support, which is shown in figure 3 , with the main elements of the piece used to visualize the number of necessary operations in the die design.

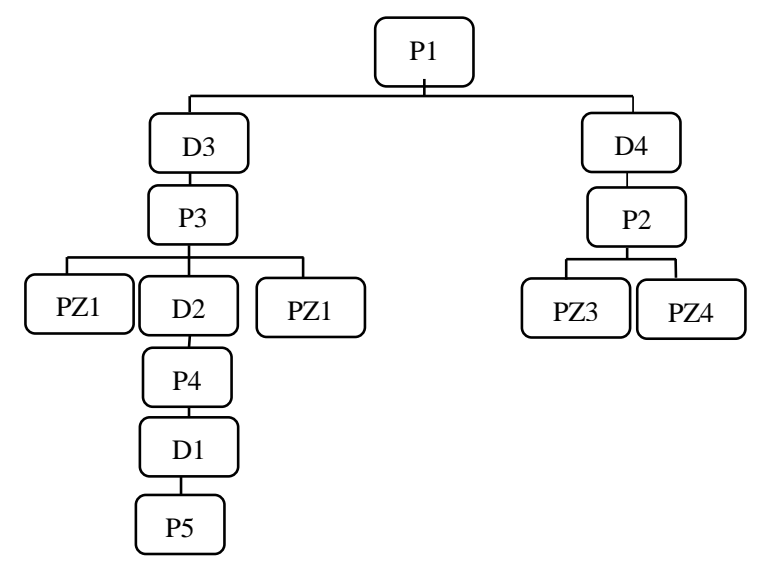

Figure 3 Relational diagram of the support. Source (project contribution, unpublished)
Figure 4 shows the steps in a schematic form of the strip of material required to obtain the product, the steps indicated are related to the operations diagram. (Enrique, 2013)

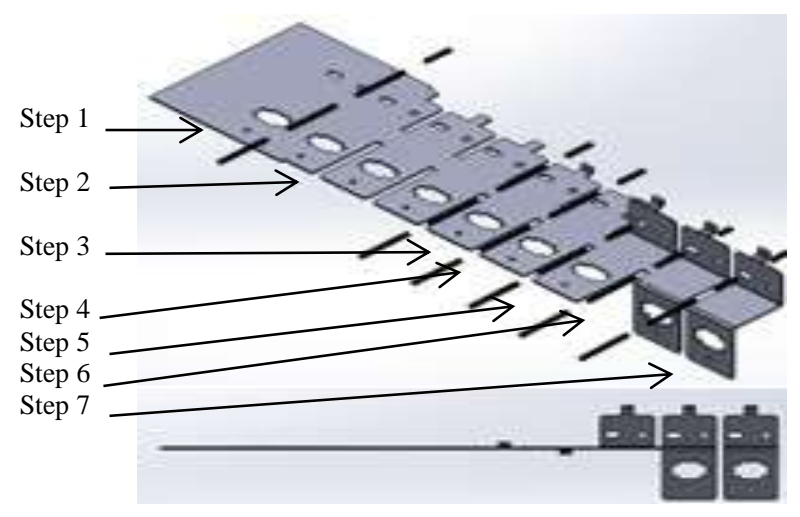

Figure 4 Steps in schematic form

Source (project contribution, unpublished)

\section{Detailed calculation stage: analysis}

In this stage, the element's shear and extraction force calculations are made, using the following equations:

For the calculation of shear force, equation 1 was used.

$\mathrm{F}=(S)(t)(K)$

And for the calculation of the extraction force of the element, equation 2 is used (Eugene A. Avallone, 2008)

$$
F_{a}=(\mathrm{F})(0.8)
$$

Table 3 shows the results of the calculations of the forces of the planes elements operations.

\begin{tabular}{|c|c|c|}
\hline \multicolumn{3}{|c|}{ Force calculations in planes } \\
\hline \multirow[b]{2}{*}{ Elements } & \multicolumn{2}{|c|}{ Results } \\
\hline & $\begin{array}{c}\text { Cutting } \\
\text { force }(\mathrm{Kg} .)\end{array}$ & $\begin{array}{l}\text { Extraction } \\
\text { force (Kg.) }\end{array}$ \\
\hline PI & 3441.28 & 275.302 \\
\hline & 21932.7984 & 175 \\
\hline
\end{tabular}

Table 3 Results of the calculation of the force of the planes

Source (project contribution, unpublished)

Table 4 shows the results of the calculations of the forces of the punching elements operations. 


\begin{tabular}{|c|c|c|}
\multicolumn{2}{|c|}{ Punching force calculations } \\
\cline { 2 - 3 } Elements & $\begin{array}{l}\text { Resultados } \\
\text { Cutting } \\
\text { force } \\
\text { (Kg.) }\end{array}$ & $\begin{array}{c}\text { Extraction } \\
\text { force } \\
\text { (Kg.) }\end{array}$ \\
\hline PZ1 & 1219.2 & 97.536 \\
\hline PZ2 & 1993.4 & 159.472 \\
\hline PZ3 & 851.154 & 68.09232 \\
\hline PZ4 & 5600.7 & 448.056 \\
\hline
\end{tabular}

Table 4 Results of calculations of punching forces. Source (project contribution, unpublished)

Equation 3 is used to calculate the force necessary to make the "L" bends.

$P=\frac{(t)(K)(\text { length })}{3}$

And for the calculation of the extraction force of the element, equation 2 is used.

Table 5 shows the results of the calculations of the bending forces operations.

\begin{tabular}{|c|c|c|}
\multicolumn{2}{|c|}{ "L" Bend Force Calculations } \\
\hline \multirow{2}{*}{ Elements } & $\begin{array}{c}\text { Bending } \\
\text { force } \\
\text { (Kg.) }\end{array}$ & $\begin{array}{c}\text { Extraction force } \\
\text { (Kg.) }\end{array}$ \\
\hline D1 & 193.548 & 15.48384 \\
\hline D2 & 193.548 & 15.48384 \\
\hline D3 & 903.224 & 72.25792 \\
\hline D4 & 903.224 & 72.25792 \\
\hline
\end{tabular}

Table 5 Results of calculations of bending forces Source (project contribution, unpublished)

The calculation of the total force is carried out using equation 4 , which is the sum of all the punching, bending and planes.

$\mathrm{F}_{\text {Total }}=\sum_{1}^{4} \mathrm{PZ}+\sum_{1}^{4} \mathrm{D}+\sum_{1}^{5} \mathrm{P}$

$\mathrm{F}_{\text {Total }}=37232.0764 \mathrm{Kg}$.

An additional factor of $10 \%$ is increased; this percentage is an experimental value to overcome the resistance of the springs and the clamp.

Once the add factor is added, a safety factor of 1 to 5 recommended by some designers is also added.

Then:

$\mathrm{F}_{\text {final }}=37232.0764 \mathrm{~kg}(0.1)+37232.0764 \mathrm{~kg}=$ $40955.28404 \mathrm{~kg}(1.2)=49146.3408 \mathrm{~kg}$.

$\mathrm{F}_{\text {final }}=49$ tons.
According to the total value of the forces, a press greater than 49 tons should be used

The calculation of the number of springs required for the extraction force is carried out.

In calculating the number of springs, equation 5 is used.

$N_{r}=\frac{F_{a}}{F_{r}}$

For the Fa Total calculation, equation 6 is used, where the sum of all extraction forces, both for punching, as well as for bends and planes, are considered.

$F_{\text {a Total }}=\sum_{1}^{4} P Z++\sum_{1}^{4} D+\sum_{1}^{1} P$

$F_{a \text { Total }}=2.9$ ton $\approx 3$ ton $=3000 \mathrm{Kg}$

\section{Springs}

The characteristics of the spring to be used are established, which are:

Spring outer diameter $=1.240$ "

Rod diameter $=0.625 "$

Free height $=3 "$.

Maximum load $=1027 \mathrm{lb}=465.75 \mathrm{Kg}$

Substituting the values of the total extraction force and the maximum spring load in equation 5 , the number of springs to be used is obtained.

$\mathrm{Nr}=6$ springs

\section{Elaboration of drawings}

Shop drawings and die part simulations are made using Solid Works software. (Gómez, 2014), which are shown in figures 5, 6, and 7.

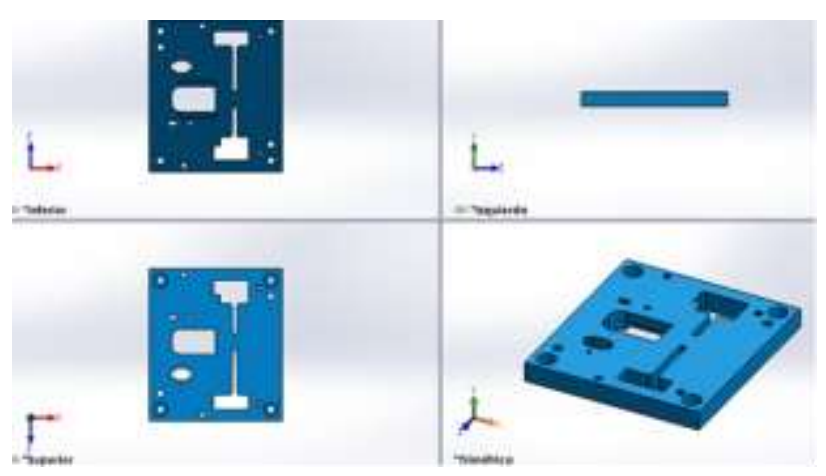

Figure 5 Cutting matrix.

Source (project contribution, unpublished)

TUDÓN-MARTÍNEZ, Alberto, ZUUÑIGA-MARTÍNEZ, Marco Antonio, GARCÍA-CASTILLO, Ilse Nallely and ROSALESGALLEGOS, Israel Atzin. Design proposal for a progressive die. Journal Innovative Design. 2021 


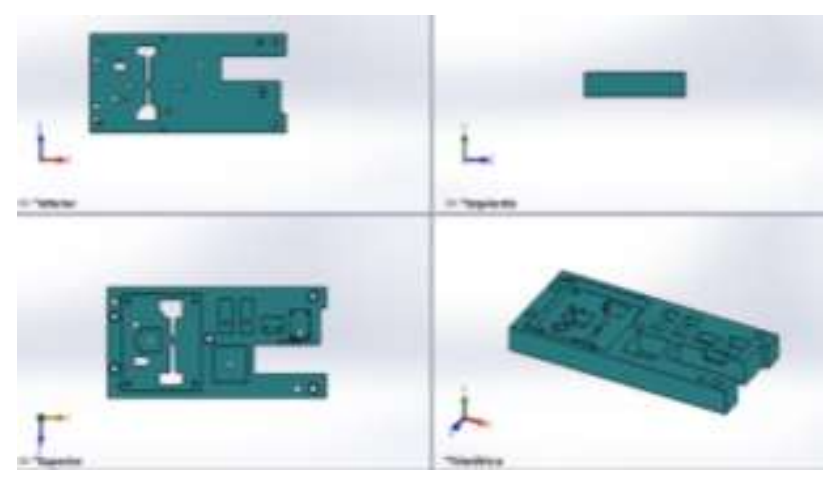

Figure 6 Lower Suffering.

Source (project contribution, unpublished)

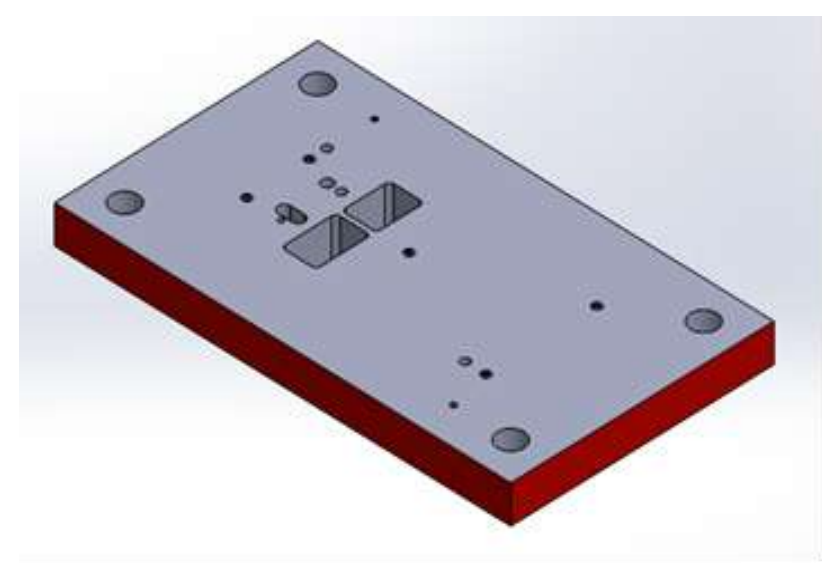

Figure 7 Lower die platen

Source (project contribution, unpublished)

\section{Evaluation Stage}

This stage is based on the dimensional part, for which a verification of its operation of the die was carried out in order to review possible interferences, part positioning errors or incorrect clearances.

This evaluation is carried out by preparing the assembly drawing in the Solid works simulator, which is shown in figure 8 , performing the opening and closing of the die, executing the interference analysis between the elements that make up the die.

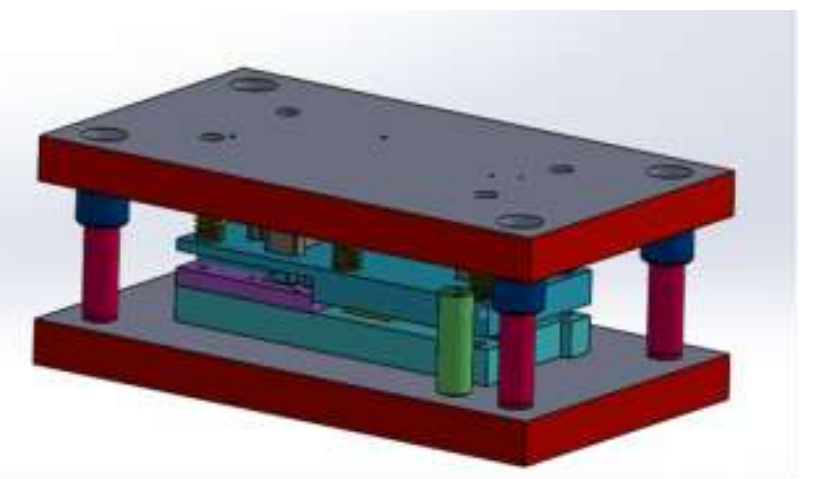

Figure 8 Complete assembly of the progressive die Source (project contribution, unpublished)

\section{Documentation stage}

Documentation is developed that identifies the main operating characteristics of the progressive die and the workpiece.

1. Tooling ID: L1221

2. Part No.: 317B8422P001

3. Die free height: 9.125 "

4. Width and length of the tooling: 26 " $\mathrm{x}$ 15 "

5. Minimum working load: 49 tons.

6. Material: Galvanized Steel.

7. Material thickness: 0.060 "

8. Material width: 4.565 "

9. Plumb: 0.050 "

\section{Results}

With this project, the objective of developing a proposal for the design of a progressive die was achieved, for the elaboration of a metallic piece (with the part number 317B8422P002), with this proposal it is intended to eliminate a cost of $99.1 \%$ of the cutting process in laser and avoid the use of more than one press for the elaboration of the bends, at the same time reducing to $90.6 \%$ of the time to obtain the first piece within the specifications of the client.

\section{Conclusions}

It is concluded that it was necessary to prepare this project, which will be possible to satisfy the needs established by the company such as:

1. Design a die with the necessary elements for the part process.

2. The general dimensions of the die will allow it to be installed in a 250-ton press existing in the company.

3. When the die is manufactured, more than $90 \%$ of the resources currently used to manufacture the part will be eliminated.

4. The design of the die includes limiting stop systems for fine tuning.

5. With the elaboration of the data sheet a good functioning and optimal operation of the die is guaranteed. 


\section{References}

Enrique, C. H. (Marzo de 2013). Desarrollo de aspectos medotodológicos en el diseño de matrices progresivas. Catabria, Santander, España.

Eugene A. Avallone, T. B. (2008). Manual del ingeniero mecánico. México, México: Mc Graw Hill.

F, A. (2003). Metodología del diseño industrial: un enfoque desde la ingeniería concurrente. México: Alfaomega.

Gómez, S. (2014). El Gran libro de solidworks. México, México: Alfaomega.

Riba, M. (Octubre de 2006). Ingenieria concurrida. Catalunya, España: Retdic.

Victorino, G. G. (2003). Análisis del proceso de diseño en ingeniería. Madrid, Madrid, España: Universidad Politécnica de Madrid. 